\title{
Kampen om «likes»
}

\author{
Hva gjør det med barn og ungdoms \\ helse og trivsel at de hele tiden \\ forholder seg til «likes» i sosiale \\ medier?
}

I mitt møte med barn og ungdom i Redd Barna forteller de ofte om et stort press på å få «likes» i sosiale medier. De begynner også ofte å snakke om «likes» når jeg møter dem for å få innspill til hva samfunnet kan gjøre for å forebygge mobbing og seksuelle overgrep.

Det er fort gjort å avfeie jaget etter «likes» som et uttrykk for at ungdom er selvopptatte og utseendefikserte. Men når jeg spør ungdom hva de legger i det, blir det tydelig at presset om å få «likes» slett ikke handler om å hevde seg i en skjønnhetskonkurranse på internett. Jeg skal forsøke å gi et glimt av det barn og ungdom har fortalt oss.

Barn og ungdom bruker utallige sosiale medier for å kommunisere med hverandre. Akkurat nå er bildedelingstjenesten Instagram populær. Her deler barn og ungdom bilder og korte filmsnutter fra dagliglivet i skolegården, blant venner eller fra fritidsaktiviteter. «Likes» har en positiv kraft som kan forsterke fellesskap blant venner og skape tilhørighet i en fritidsaktivitet eller i en skoleklasse. De som ellers ikke tør å si noe høyt i klassen og som er litt utenfor i skoletiden, kan oppleve å bli inkludert i en gruppe i sosiale medier.

Men «likes» har sine slagsider. Det sosiale livet i klassen, på skolen og blant venner blir hele tiden målt i antall «likes»:
Det er et åpent barometer på popularitet og status. Alle kan se hvem som får mange «likes», få «likes» og hvem som knapt får én eneste en. Noen får ingen reaksjoner, og det er synlig. Det kan forsterke opplevelsen av å være utenfor.

Det er et stort kropps-og utseendepress, forteller ungdom. Et pent portrett gir mange «likes». A teste ut hva som gir mange «likes», kan innebære en følelsesmessig og reell risiko: Hvor langt er man villig til å gå for å få «likes»? Ungdom selv kan være nådeløse i dommen over jevnaldrende som deler for seksualiserte bilder og/eller lager seksualiserte emneknagger på åpne profiler. I tillegg kan det å dele utfordrende bilder på åpne profiler med seksualiserte emneknagger øke sår barhet for tilnærmelser, krenkelser og seksuelle overgrep.

«Likes» brukes oftest for å få bekreftelse på positive ting. Men ønsket om «likes», om å bli sett, kan føre til at noen eksponerer vanskelige, private og vonde ting. Det kan gi mange «likes», men det kan bli en kortvarig positiv følelse hvis man ikke har gode venner som gir støtte eller har voksne rundt seg som følger opp de problemene som barna sliter med. Det kan også få negative konsekvenser i kontakten med jevnaldrende, som kan snakke nedlatende om andre ungdommer som roper etter oppmerksomhet og «likes» ved å snakke seg selv ned i sosiale medier.

Et annet eksempel på problematisk bruk av «likes» er at det kan brukes til å plage eller mobbe andre. Offentlig uthenging i sosiale medier er ikke uvanlig, og det gjør saken enda verre at elever og andre trykker «like» på noe som oppfattes som erting, mobbing eller uthenging. Den offentlige ydmykelsen blir tallfestet i antall «likes».

Det er derfor forståelig at «likes» er et tema som går igjen i våre samtaler med barn og ungdom om mobbing og seksuelle overgrep. Det er viktig å få mer kunnskap om hva dette gjør med barna og hvilke konsekvenser det har for utviklingen og trivselen at vi kommuniserer med synlige og tilgjengelige «likes» i sosiale medier, uten korrektiv og tilstedeværelse fra voksne omsorgspersoner.

Vi må snakke med barn og ungdom om deres digitale opplevelser og ikke se på det som «noe annet», uvirkelig og mindre viktig enn det som skjer ellers. Vi må stille spørsmål om betydningen av «likes» og hvorfor de fordømmer andre som tar risikoer eller eksponerer seg så mye. Hvilke normer ligger til grunn for det?

Møter du et barn som tar risikoer eller er innesluttet, så spør om «likes». Opplever de å ikke få «likes», er de veldig opptatt av å få mange «likes» eller er det kanskje ikke så viktig for dem? Spør! Det kan handle om å føle seg usynlig, om å mangle bekreftelse eller vennskap - store og viktige temaer i barn og ungdoms liv.

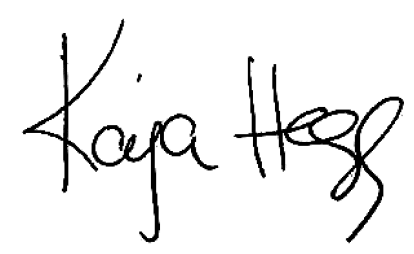

